\title{
Ruminal fermentation and enteric methane production of legumes containing condensed tannins fed in continuous culture
}

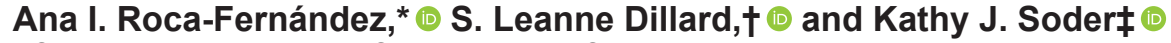 \\ USDA-Agricultural Research Service, Pasture Systems and Watershed Management Research Unit, University Park, PA $16802-3702$
}

\begin{abstract}
A continuous-culture fermentor study was conducted to assess nutrient digestibilities, volatile fatty acid (VFA) concentrations, microbial protein synthesis, bacterial nitrogen $(\mathrm{N})$ efficiency, and enteric methane $\left(\mathrm{CH}_{4}\right)$ production of four 50:50 grass-legume diets, randomly assigned in a $4 \times 4$ Latin square design. Four legumes with different concentrations of condensed tannins (CT) were tested: alfalfa [ALF; Medicago sativa L., non-CT legume]; birdsfoot trefoil [BFT; Lotus corniculatus L., low-CT legume]; crown vetch [CV; Securigera varia (L.) Lassen, moderate-CT legume]; and sericea lespedeza [SL; Lespedeza cuneata (Dum. Cours.) G. Don, highCT legume]. Orchardgrass (Dactylis glomerata L.) was the common forage used in all diets. Four fermentors were evaluated over four 10-d periods by feeding $82 \mathrm{~g}$ of dry matter $(\mathrm{DM}) / \mathrm{d}$ in 4 equal feedings. Methane output was recorded every $10 \mathrm{~min}$. Effluent samples were collected during the last $3 \mathrm{~d}$ of the experiment, composited by fermentor and period, and analyzed for $\mathrm{pH}$ and VFA, as well as DM, organic matter, crude protein, neutral detergent fiber, and acid detergent fiber for determination of apparent and true nutrient digestibilities. Microbial protein synthesis and bacterial efficiency were estimated by analysis of $\mathrm{N}$ flows and purines. The CT concentrations were $3,21,38$ and 76 $\mathrm{g} / \mathrm{kg}$ of DM for ALF, BFT, CV, and SL diets, respectively. The SL diet had decreased fiber digestibilities and total VFA concentrations compared with the other diets. This resulted in the least total $\mathrm{CH}_{4}$ production in the SL diet. Bacterial N efficiency per kilogram of
\end{abstract}

Received September 23, 2019.

Accepted March 12, 2020.

*Current address: Departamento de Producción Vegetal y Proyectos de Ingeniería, Escuela Politécnica Superior de Ingeniería, Universidad de Santiago de Compostela, 27002 Lugo, Spain.

$\dagger$ Current address: Department of Animal Sciences and Department of Crop, Soil, and Environmental Sciences, Auburn University, Auburn, AL 36803.

‡Corresponding author: Kathy.Soder@usda.gov organic matter truly digested was lower in the SL diet than in the BFT and $\mathrm{CV}$ diets. The lowest $\mathrm{CH}_{4}$ production per unit of digestible nutrients was also found in the SL diet. Further work should be conducted to find optimal diets (by testing other legumes, rations, and sources of $\mathrm{CT}$ ) for reducing $\mathrm{CH}_{4}$ emissions without negatively affecting ruminal digestion to maintain or improve productivity.

Key words: condensed tannin, digestibility, legume, methane

\section{INTRODUCTION}

Plant secondary metabolites (PSM) such as tannins, saponins, and essential oils are recognized as bioactive modifiers and methanogenesis inhibitors in the rumen (Patra and Saxena, 2010). These PSM are mainly characterized as modulators of microbial populations (Bodas et al., 2012) by changing ruminal fermentation process, modifying nutrient digestion, and altering biohydrogenation of fatty acids (Theodoridou et al., 2010). Incorporating PSM in animal diets have been shown to reduce methane $\left(\mathrm{CH}_{4}\right)$ production and decrease risk of metabolic diseases (such as bloat or acidosis), thus improving ruminant productivity and health (Moore et al., 2008; Rochfort et al., 2008).

Tannins are a group of polyphenolic compounds found in forages and other feeds commonly used for feeding ruminants, including trees, shrubs, legumes, cereals, and grains (Patra and Saxena, 2011). Condensed tannins (CT) comprise 1 of 2 large groups of tannins, designated as proanthocyanidins, and are one of the most ubiquitous compounds in the plant kingdom (Yoshida et al., 2005). Condensed tannins are found in the leaves, stems, flowers, and seeds of several legumes (Li et al., 2014). Chemical structure and concentration of CT vary among plant species, growth stages, and growing conditions, such as temperature, light intensity, nutrient stress, and even plant exposure to herbivory (Li et al., 2014). Legumes containing CT are currently gaining interest in ruminant nutrition studies (Broderick et al., 2017) due to interactions with rumen 
microbiota (Díaz Carrasco et al., 2017), which then affect carbohydrate fermentation, protein degradation, and lipid metabolism (Vasta et al., 2019).

Condensed tannins have been shown to prevent bloat (Min et al., 2006), decrease internal parasite loads (Athanasiadou et al., 2001), and reduce enteric $\mathrm{CH}_{4}$ emissions (Puchala et al., 2012). Overall, the inhibitory effects of $\mathrm{CT}$ on ruminal methanogenesis have been ascribed to directly reducing $\mathrm{CH}_{4}$ production associated with methanogenic archaea or protozoa while indirectly depressing ruminal fiber digestion (Patra and Saxena, 2010). It is generally agreed that adding $\mathrm{CT}$ to diets may be predominantly beneficial for reducing degradation of proteins and improving RUP, by decreasing ammonia $\left(\mathrm{NH}_{3}-\mathrm{N}\right)$ concentrations in the rumen (Patra and Saxena, 2010). The binding ability of specific tannin-proteins determines the effects of CT legumes on protein degradability in the digestive tract by inhibiting the availability of nutrients to be used by rumen microorganisms (Kamra et al., 2008). Although legumes hold promise in terms of $\mathrm{CH}_{4}$ abatement (Animut et al., 2008a,b), the forage sources and optimum $\mathrm{CT}$ concentrations to ensure that $\mathrm{CH}_{4}$ emissions are lowered without negatively affecting nutrient digestion and animal performance are variable (Williams et al., 2011). Legumes containing low to moderate concentrations of CT $(<50 \mathrm{~g} / \mathrm{kg}$ of DM), such as birdsfoot trefoil (Lotus corniculatus L.) and crown vetch [Securigera varia (L.) Lassen], may benefit ruminants by improving protein utilization (Aerts et al., 1999) without negatively affecting intake and nutrient digestion (Patra and Saxena, 2011). However, legumes containing high CT concentrations (60-120 g/ $\mathrm{kg}$ of DM), such as sericea lespedeza [Lespedeza cuneata (Dum. Cours.) G. Don], may depress intake, digestive efficiency, and animal productivity (Aerts et al., 1999). Combining forages containing $\mathrm{CT}$ with orchardgrass (non-CT) may be an alternative feeding strategy for farmers, particularly producers with grass-fed herds who cannot use supplements to decrease $\mathrm{CH}_{4}$ emissions in forage-based systems.

To our knowledge, no previous studies have investigated how incorporating legumes of varying CT concentrations into a $50 \%$ orchardgrass (Dactylis glomerata L.) diet will affect in vitro ruminal fermentation and enteric $\mathrm{CH}_{4}$ production. Therefore, the objective of the current experiment was to determine the effect of 4 perennial legumes containing increasing CT concentrations on nutrient digestibilities, VFA production, microbial protein synthesis, bacterial $\mathrm{N}$ efficiency, and enteric $\mathrm{CH}_{4}$ production of an orchardgrass-based diet. We hypothesized that the incorporation of a high CT-concentration legume (sericea lespedeza) to a non-
$\mathrm{CT}$ orchardgrass diet would reduce $\mathrm{CH}_{4}$ production; however, there would be a negative effect on ruminal fermentation, specifically nutrient digestibilities, which may have potential to reduce animal productivity.

\section{MATERIALS AND METHODS}

\section{Site, Diets, and Experimental Design}

This study was conducted at the USDA-Agricultural Research Service Pasture Systems and Watershed Management Research Unit (University Park, PA) from February to April 2016. Orchardgrass herbage was harvested on May 15 and June 27, 2015, from a 2-yrold monoculture established at the Pennsylvania State University Russell Larson Agricultural Research Farm (Rock Springs, PA). Orchardgrass was harvested at a vegetative stage of growth $(36 \mathrm{~cm}$ tall; $21 \% \mathrm{DM})$, typical of high-quality pastures found in temperate regions of the United States (Soder et al., 2013). Alfalfa [Medicago sativa L. 'Pioneer 55H94' and 'WL353LH'] was harvested on August 13, 2015, from 2 separate plots of a multiple-year monoculture established at the Pennsylvania State University Haller Fam (State College, PA) at flowering stage (53 cm tall; $27 \% \mathrm{DM}$ ). 'Ober' birdsfoot trefoil was harvested on July 17 and August 27, 2015, from a 1-yr-old monoculture planted at the Russell Larson Agricultural Research Farm (Rock Springs, PA), at a vegetative stage of growth (20 cm tall; $25 \%$ DM). The site consisted of a Hagerstown silt loam soil (Fine, mixed, semiactive, mesic Typic Hapludalfs) with 3 to $8 \%$ slopes. Potassium and $\mathrm{P}$ were applied based on soil test recommendations at the time of planting, and $\mathrm{N}$ was applied early- and mid-season using the Pennsylvania State University Extension recommendation for each forage species. Crown vetch was harvested on July 24, 2015 from a multiple-year monoculture established on a commercial farm in Warriors Mark, Pennsylvania, at flowering stage (48 cm tall; $57 \% \mathrm{DM})$. Sericea lespedeza was harvested on July 10 and July 30, 2015 from a multiple-year monoculture planted at the University of Kentucky Spindletop Research Farm (Lexington, KY) at flowering stage (90 $\mathrm{cm}$ tall; $41 \%$ DM). The site consisted of a Bluegrass-Maury silt loam soil (Fine, mixed, active, mesic Typic Paleudalfs) with 2 to $6 \%$ slope. Potassium and $\mathrm{P}$ were applied based on soil test recommendation at the time of planting, and $\mathrm{N}$ was applied early- and mid-season using the University of Kentucky recommendation for sericea lespedeza. Soil tests were routinely conducted in each of the plots under study. A plot harvester (HEGE 212; Wintersteiger AG, Waldenburg, Germany; 1.5-m-wide swath), set to a $10-\mathrm{cm}$ stubble height, was used to harvest all plots 
in the morning (at maximum $25-30^{\circ} \mathrm{C}$ ). Within $30 \mathrm{~min}$ of harvest, all forages were placed in cloth bags and frozen $\left(-4^{\circ} \mathrm{C}\right)$ until being freeze-dried (Ultra 35 Super ES; Virtis Co. Inc., Gardiner, NY). Freeze-dried forage samples were ground to pass through a 2-mm sieve (Wiley mill; Thomson Scientific Inc., Philadelphia, PA).

\section{Continuous-Culture System and Fermentor Operation}

The continuous-culture fermentor study was conducted at the USDA-Agricultural Research Service, Pasture Systems and Watershed Management Research Unit (University Park, PA) from May to July 2016. Total DM fed to all fermentors was fixed at $82 \mathrm{~g} / \mathrm{d}$ for the duration of the experiment. Diets were randomly assigned to fermentors in a $4 \times 4$ Latin square design during 4 consecutive 10-d periods. Four legumes, containing increasing CT concentrations, were tested: alfalfa (ALF; no-CT legume), birdsfoot trefoil (BFT; low-CT legume), crown vetch (CV; moderate-CT legume), and sericea lespedeza (SL; high-CT legume). Orchardgrass was the common ingredient used in all diets. Representative samples of freeze-dried forages were collected from each diet at the beginning of this study and analyzed for nutrient concentrations at a commercial laboratory (Dairy One Laboratories, Ithaca, NY; results are presented in Table 1).

For this study, a 4-unit single-flow continuous-culture fermentor system (Applikon Biotechnology, B.V., Schideam, the Netherlands; Dillard et al., 2019) was used. Fermentors were fed 4 times daily (0730, 1030,
1400 , and $1900 \mathrm{~h}$ ) in equal proportions to simulate diurnal patterns in grazing. Solid mean retention time and liquid dilution rate of the fermentors were adjusted daily to $24 \mathrm{~h}$ and $10 \% / \mathrm{h}$, respectively, which was achieved by regulation of buffer input and effluent volume removal. A full description of continuous-culture operation to determine total effluent volume removed per day has been described by Dillard et al. (2019).

Ruminal fluid and digesta samples were collected from a ruminally fistulated, nonlactating, nonpregnant 4-yr-old Holstein cow (794 kg of BW) cared for in accordance with the Pennsylvania State University Animal Care and Use (IACUC no. 46212) guidelines. The donor animal was housed and maintained on a diet of silage, hay, and grain (75:25 forage-to-concentrate ratio, ad libitum) in a feed bunk for a total of $13.8 \mathrm{~kg}$ of DM of available feed per cow per day at the Pennsylvania State University Dairy Research Farm (University Park, PA). The total mixed ration contained a vitamin and mineral premix at $1.8 \%$ of total DMI, which was included to meet NRC (2001) nutrient recommendations for a nonlactating dairy cow. Approximately $3 \mathrm{~h}$ after feeding, $7 \mathrm{~L}$ of ruminal fluid was collected with a hand pump into a prewarmed insulated container and maintained at $39^{\circ} \mathrm{C}$. Solid digesta was collected by hand from the ventral, central, and dorsal areas of the rumen. Liquid and whole digesta samples were transported to the USDA-Agricultural Research Service laboratory in separate containers. Within 15 min of collection, fluid was strained through 4 layers of cheesecloth and 1.50 $\mathrm{L}$ was poured into each of the prewarmed fermentation jars until it cleared the overflow spout. Solid digesta

Table 1. Chemical composition of forages and diets fed during continuous-culture fermentation

\begin{tabular}{|c|c|c|c|c|c|c|c|c|c|}
\hline \multirow[b]{2}{*}{ Item $^{1}$} & \multicolumn{5}{|c|}{ Forage } & \multicolumn{4}{|c|}{$\operatorname{Diet}^{2}$} \\
\hline & Orchardgrass & Alfalfa & $\begin{array}{c}\text { Birdsfoot } \\
\text { trefoil }\end{array}$ & $\begin{array}{c}\text { Crown } \\
\text { vetch }\end{array}$ & $\begin{array}{c}\text { Sericea } \\
\text { lespedeza }\end{array}$ & $\mathrm{ALF}$ & BFT & $\mathrm{CV}$ & SL \\
\hline $\mathrm{CP}(\%)$ & 23.0 & 26.6 & 17.5 & 16.1 & 11.9 & 24.8 & 20.3 & 19.6 & 17.5 \\
\hline $\mathrm{RDP}(\%$ of $\mathrm{CP})$ & 79.0 & 82.0 & 69.0 & 65.0 & 32.0 & 80.5 & 74.0 & 72.0 & 55.5 \\
\hline $\mathrm{SP}(\%$ of $\mathrm{CP})$ & 38.0 & 51.0 & 31.0 & 47.0 & 30.0 & 44.5 & 34.5 & 42.5 & 34.0 \\
\hline Lignin (\%) & 6.3 & 10.0 & 3.6 & 12.5 & 6.3 & 8.2 & 5.0 & 9.4 & 6.3 \\
\hline $\mathrm{NFC}^{3}(\%)$ & 10.8 & 27.2 & 55.3 & 18.6 & 29.1 & 19.0 & 33.0 & 14.7 & 19.9 \\
\hline Ether extract (\%) & 3.40 & 2.20 & 3.20 & 3.20 & 2.90 & 2.80 & 3.30 & 3.30 & 3.15 \\
\hline TDN $(\%)$ & 60.0 & 59.0 & 75.0 & 52.0 & 63.0 & 59.5 & 67.5 & 56.0 & 61.5 \\
\hline RFV & 107 & 183 & 416 & 93 & 96 & 145 & 262 & 100 & 102 \\
\hline $\mathrm{CT}(\mathrm{g} / \mathrm{kg}$ of DM) & 3.5 & 2.3 & 38.3 & 72.4 & 147.7 & 2.9 & 20.9 & 38.0 & 75.6 \\
\hline
\end{tabular}

${ }^{1} \mathrm{SP}=$ soluble protein; $\mathrm{RFV}=$ relative feed value; $\mathrm{CT}=$ condensed tannins.

${ }^{2}$ Calculated using actual nutrient composition and proportion of individual ingredients (DM basis); ALF $=50 \%$ orchardgrass $+50 \%$ alfalfa; $\mathrm{BFT}=50 \%$ orchardgrass $+50 \%$ birdsfoot trefoil $\mathrm{CV}=50 \%$ orchardgrass $+50 \%$ crown vetch; $\mathrm{SL}=50 \%$ orchardgrass $+50 \%$ sericea lespedeza. ${ }^{3}$ Calculated as NFC $(\%)=100-[\mathrm{CP}(\%)+$ NDF $(\%)+$ ether extract $(\%)+$ ash $(\%)]$. 
was mixed by hand and $32 \mathrm{~g}$ was added to each vessel following the protocol of Dillard et al. (2019).

Each of the 4 periods consisted of a 7-d diet adaptation followed by a $3-\mathrm{d}$ sampling collection. During the $10 \mathrm{~d}$ of each period, effluent was collected in 4-L plastic containers located inside of a freezer to maintain an effluent temperature of $4^{\circ} \mathrm{C}$ and inhibit microbial fermentation (Dillard et al., 2019). During the 7-d adaptation period, the overflow containers were weighed daily and then the contents discarded. During the 3-d collection period, daily effluent collections were mixed according to the methods of Soder et al. (2016).

Daily effluent samples (100 mL/sample) were taken inside of each vessel for protozoal count during the $3-\mathrm{d}$ collection period immediately before the $1030 \mathrm{~h}$ feeding. Vessel protozoal cell counts were completed using the Sedgewick-Rafter chamber by Dehority (2005). A 50$\mathrm{mL}$ sample of effluent was also collected on the 3 collection days and strained through 8 layers of cheesecloth. Then, $3 \mathrm{~mL}$ of $25 \%$ (vol/vol) $m$-phosphoric acid was added to $15 \mathrm{~mL}$ of filtrated sample for determination of $\mathrm{NH}_{3}-\mathrm{N}$ (Chaney and Marbach, 1962), and for VFA (Erwin et al., 1961) via gas chromatography [Varian 330 Gas Chromatograph (FID detector), Varian 4290 Integrator; Supelco, 1975, modified to use a 80/120 Carbopack B-DA/4\% Carbowax 20M column] at the Rumen Fermentation Profiling Laboratory (West Virginia University, Morgantown).

An additional $1 \mathrm{~L}$ of effluent was collected each day of the collection period and composited at the end of each period. Composited effluent samples were freezedried, ground to pass through a 1-mm sieve, and stored in a sealed plastic bag for later analyses of DM, OM, NDF with $\alpha$-amylase, ADF, CP (AOAC International, 2006), and total purines (Makkar and Becker, 1999). During the last day of each period, the contents of each fermentor vessel were processed for bacterial isolation according to the methods of Griswold et al. (1996) with the modification used by Soder et al. (2016) of replacing initial centrifugation for blending particulatephase bacteria for $30 \mathrm{~s}$ and strained through 2 layers of 53- $\mu \mathrm{m}$ Nitex fabric (Wildco, Buffalo, NY) into a 2-L plastic container with $5 \mathrm{~mL}$ of $50 \%$ sulfuric acid added to retard microbial growth. Concentrations of total purines in effluent and bacterial isolates were then used to partition effluent $\mathrm{N}$ flow into bacterial and nonbacterial fractions, and to calculate true DM and OM digestibilities and flows by using the equations of Soder et al. (2016).

\section{Methane Collection and Measurements}

Methane measurements were taken every 10 min using a photoacoustic gas monitor (LumaSense Technolo- gies Inc., Santa Clara, CA) connected to a multiport sampler (CAI, Inc., Orange, CA) that directed the flow of gas from each vessel. Each cycle required 140 $\mathrm{cm}^{3}$ of the approximately $1,500-\mathrm{mL}$ of headspace gas available. Total daily $\mathrm{CH}_{4}$ production was calculated by determining the difference in $\mathrm{CH}_{4}$ volume (measured $\mathrm{CH}_{4}$ concentration multiplied by the headspace volume) between each of the 10-min samples, and then summing these values for every 24 -h period during the collection days following the equations of Dillard et al. (2019). Thus, total daily $\mathrm{CH}_{4}$ production $=\Sigma\left[\mathrm{CH}_{4}\right.$ volume $_{\mathrm{a}}-\mathrm{CH}_{4}$ volume $\mathrm{b}$ ], where $\mathrm{CH}_{4}$ volume $\mathrm{a}_{\mathrm{a}}$ equals $\mathrm{CH}_{4}$ volume determined by multiplying the headspace volume by the measured $\mathrm{CH}_{4}$ concentration, and $\mathrm{CH}_{4}$ volume ${ }_{\mathrm{b}}$ equals $\mathrm{CH}_{4}$ volume $10 \mathrm{~min}$ before $\mathrm{CH}_{4}$ volume over each 24-h period.

\section{Nutrient Analyses}

Forage samples of orchardgrass, alfalfa, birdsfoot trefoil, crown vetch, and sericea lespedeza were analyzed by wet chemistry (Dairy One Laboratories, Ithaca, NY) according to the following procedures: DM (method 930.15; AOAC International, 2006), CP (method 990.03; AOAC International, 2006), RDP (Cornell Streptomyces griseus enzymatic digestion; Coblentz et al., 1999), soluble protein (SP; Licitra et al., 1996), ether extract (method 2003.05; AOAC International, 2006), and NDF [Ankom Technology method 6 (NDF in Feeds - Filter Bag Technique for A200; Fairport, NY); with heat-stable $\alpha$-amylase and sodium sulfite used in the NDF procedure (inclusive of ash); Mertens (2002)]. The NFC were calculated using the equation: NFC $(\%)=100-[\mathrm{CP}(\%)+\mathrm{NDF}(\%)+$ ether extract $(\%)+$ ash (\%)]. Condensed tannin concentrations were determined by following the methods of Grabber et al. (2013), using butanol-HCl-iron assay, at the Department of Plants, Soils, and Climate (Utah State University, Logan, Utah).

Effluent samples and microbial pellets were analyzed for DM, OM (methods 930.15 and 942.05, respectively; AOAC International, 2006), and CP concentrations (micro-Kjeldahl digestion using 75 -mL calibrated tubes with $\mathrm{CuSO}_{4} / \mathrm{K}_{2} \mathrm{SO}_{4}$ catalyst; method 976.06 ; AOAC International, 2006). The NDF concentration of the effluent was determined by the methods of Van Soest et al. (1991) with $\alpha$-amylase and sodium sulfite used in the NDF procedure (inclusive of ash). Concentrations of total purines (Makkar and Becker, 1999) in effluent and microbial isolates were used to partition effluent $\mathrm{N}$ flow into bacterial and nonbacterial fractions, and to calculate true DM and OM digestibilities and flows. Apparent (DM, OM, CP, NDF, and ADF) and true (DM and $\mathrm{OM}$ ) digestibilities of nutrients, $\mathrm{N}$ fractions 
flow, and bacterial efficiency were calculated using the equations previously reported by Soder et al. (2016).

\section{Statistical Analyses}

All data were analyzed as a $4 \times 4$ Latin square design using the GLIMMIX procedure of SAS (SAS Institute Inc., Cary, NC), fitted to the following model:

$$
\mathrm{Y}_{i j k}=\mu+\mathrm{P}_{i}+\mathrm{F}_{j}+\mathrm{D}_{k}+\mathrm{e}_{i j k}
$$

where $\mathrm{Y}_{i j k}=$ observations for dependent variables, $\mu=$ population mean, $\mathrm{P}_{i}=$ mean effect of $i$ th period, $\mathrm{F}_{j}=$ mean effect of $j$ th fermentor, $\mathrm{D}_{k}=$ mean effect of $k$ th diet, and $\mathrm{e}_{i j k}=$ residual error. Period and diet were fixed effects, while fermentor and residual error were random effects.

For all statistical analyses, significance was declared at $P \leq 0.05$, and tendencies at $0.05<P \leq 0.10$ after application of Fisher's least significance difference protected test. There were no period $\times$ fermentor or period $\times$ diet interactions; therefore, only main effects are reported below.

\section{RESULTS AND DISCUSSION}

\section{Diet Composition and Donor Rumen Fluid}

Chemical composition of forages and diets are reported in Table 1. The use of composite sampling for nutrient and $\mathrm{CT}$ analyses precluded statistical comparisons among diets. The SL diet had the lowest numerical CP, RDP, and SP concentrations, whereas the ALF diet showed the greatest values. The CV and SL diets showed the greatest numerical NDF and ADF concentrations, whereas the BFT diet showed the low- est values. The BFT diet had the greatest NFC and relative feed value. Concentrations of $\mathrm{CT}$ were numerically the lowest in ALF diet and the greatest in the SL diet, with the BFT and $\mathrm{CV}$ diets showing intermediate levels.

Concentrations of CT for the birdsfoot trefoil and sericea lespedeza were within the range of those previously found by Jonker and $\mathrm{Yu}(2017 ; 21-47 \mathrm{~g} / \mathrm{kg}$ of DM) and Müir et al. (2018; 121-142 g/kg of DM). However, alfalfa and crown vetch showed numerically higher CT concentrations than those reported by Jonker and $\mathrm{Yu}(2017 ; 0.5 \mathrm{~g} / \mathrm{kg}$ of $\mathrm{DM})$ and Terrill et al. (1992; $16 \mathrm{~g} / \mathrm{kg}$ of DM), respectively. Those differences might be due to variations in soil fertility (Barry and Forss, 1983), growth conditions (Li et al., 2014), harvesting stages (Schreurs et al., 2007), or methodology used for analyses (Terrill et al., 1992).

While the use of a single donor cow for rumen fluid has been accepted for in vitro research (e.g., Foskolos et al., 2015; Lascano et al., 2016; Dillard et al., 2017), it has become more commonplace to use multiple donor animals to reduce variation in source of rumen inoculum. However, Yáñez-Ruiz et al. (2016) found no research assessing the minimum number of donor animals needed to provide a representative source of rumen inoculum from a statistical analysis perspective. Additionally, animal welfare and institutional animal care and use committee concerns also monitor and emphasize the use of the minimum number of animals in research. Given that the main goal of in vitro systems is to compare relative differences between treatments within a study, and not make absolute numerical comparisons to in vivo conditions, the use of a single donor cow provides such a means when animal numbers are limiting or animal welfare concerns are at the forefront.

Table 2. Nutrient digestibilities of alfalfa, birdsfoot trefoil, crown vetch, and sericea lespedeza fed with orchardgrass during continuous-culture fermentation

\begin{tabular}{lcccccc}
\hline & \multicolumn{9}{c}{ Diet $^{1}$} \\
\cline { 2 - 4 } Item & ALF & BFT & CV & SL & SEM & $P$-value \\
\hline Apparent digestibility (\%) & $45.7^{\mathrm{a}}$ & $45.6^{\mathrm{a}}$ & $44.0^{\mathrm{b}}$ & $40.3^{\mathrm{c}}$ & 0.66 & $<0.001$ \\
DM & $61.9^{\mathrm{a}}$ & $61.1^{\mathrm{a}}$ & $59.6^{\mathrm{b}}$ & $56.1^{\mathrm{c}}$ & 0.65 & $<0.001$ \\
OM & $52.9^{\mathrm{a}}$ & $53.2^{\mathrm{a}}$ & $51.6^{\mathrm{a}}$ & $39.4^{\mathrm{b}}$ & 1.42 & $<0.001$ \\
NDF & $53.4^{\mathrm{a}}$ & $53.9^{\mathrm{a}}$ & $51.1^{\mathrm{a}}$ & $33.8^{\mathrm{b}}$ & 1.83 & $<0.001$ \\
ADF & & & & & & \\
True digestibility (\%) & $69.2^{\mathrm{b}}$ & $75.1^{\mathrm{a}}$ & $68.7^{\mathrm{bc}}$ & $64.1^{\mathrm{c}}$ & 1.57 & 0.006 \\
DM & $77.5^{\mathrm{b}}$ & $81.3^{\mathrm{a}}$ & $76.6^{\mathrm{b}}$ & $70.5^{\mathrm{c}}$ & 1.02 & $<0.001$ \\
OM & &
\end{tabular}

${ }^{\mathrm{a}-\mathrm{c}}$ Mean values in the same row with different superscripts differ $(P<0.05)$.

${ }^{1} \mathrm{ALF}=50 \%$ orchardgrass $+50 \%$ alfalfa; $\mathrm{BFT}=50 \%$ orchardgrass $+50 \%$ birdsfoot trefoil $\mathrm{CV}=50 \%$ orchardgrass $+50 \%$ crown vetch; $\mathrm{SL}=50 \%$ orchardgrass $+50 \%$ sericea lespedeza. 


\section{Nutrient Digestibilities}

Apparent $\mathrm{DM}$ and $\mathrm{OM}$ digestibilities were lowest $(P<0.001)$ for SL, intermediate for $\mathrm{CV}$, and highest in ALF and BFT diets (Table 2). Apparent NDF and ADF digestibilities were decreased $(P<0.001)$ in the SL compared with the other diets. True DM digestibilities were greater $(P=0.006)$ in BFT. True OM digestibilities were greatest $(P<0.001)$ in the BFT diet and lowest in SL.

Decreased fiber digestibilities of the SL diet were likely a result of high indigestible fiber fractions in that legume compared with the others (Buxton and Redfearn, 1997). The reduced nutrient digestibilities in the SL diet agree with previous results, where tannin extracts or tannin-containing plants are used, at concentrations $>5 \mathrm{~g}$ of $\mathrm{CT} / \mathrm{kg}$ of $\mathrm{DM}$, both in vitro (Bhatta et al., 2009) and in vivo (Animut et al., 2008a,b). It is generally suggested that high CT concentrations may have adverse effects on nutrient utilization and productivity of animals, but the response is dependent on the type of tannins (Waghorn, 2008). Moderate to high CT concentrations have been shown to exert antimicrobial actions in the rumen (Patra and Saxena, 2009), which provoke adverse effects on ruminal fermentation and digestion of feeds, and may explain why nutrient digestibilities were lower for SL than for the other 3 diets. Additionally, depressed fiber digestibilities in SL might be due to reduced degradation of fiber by preventing the attachment of microorganisms to plant cell walls (McAllister et al., 1994), inhibiting microbial degrading enzymes, or altering the functionality of ruminal microorganisms (Jones et al., 1994).

\section{Fermentor $\mathrm{pH}$, Protozoal Counts, and VFA Production}

The SL diet had higher $(P<0.05)$ mean $\mathrm{pH}$ than the ALF and BFT diets, but was not different from the CV diet (Table 3). Greater pH in SL might be attributed to better buffering capacity in that legume due to higher $\mathrm{CT}$ concentrations and lower RDP. Fermentor minimum $\mathrm{pH}$ was lower $(P<0.05)$ in the BFT diet than in the CV and SL diets, with ALF diet being intermediate. Maximum fermentor $\mathrm{pH}$ was greater $(P$ $<0.05)$ in the SL diet compared with the other 3 diets. According to Van Soest (1994), low-fiber diets (such as those found at the current trial in BFT) tend to have higher rates of digestion and acid production, thereby substantially lower ruminal $\mathrm{pH}$. This agrees with other

Table 3. Fermentor pH, VFA concentrations and molar proportions, protozoal count, and total $\mathrm{CH}_{4}$ production of alfalfa, birdsfoot trefoil, crown vetch, and sericea lespedeza fed with orchardgrass during continuous-culture fermentation

\begin{tabular}{|c|c|c|c|c|c|c|}
\hline \multirow[b]{2}{*}{ Item } & \multicolumn{4}{|c|}{$\operatorname{Diet}^{1}$} & \multirow[b]{2}{*}{ SEM } & \multirow[b]{2}{*}{$P$-value } \\
\hline & ALF & BFT & $\mathrm{CV}$ & $\mathrm{SL}$ & & \\
\hline \multicolumn{7}{|l|}{$\mathrm{pH}$} \\
\hline Mean & $6.52^{\mathrm{b}}$ & $6.41^{\mathrm{b}}$ & $6.60^{\mathrm{ab}}$ & $6.80^{\mathrm{a}}$ & 0.075 & 0.026 \\
\hline Minimum & $6.37^{\mathrm{ab}}$ & $6.19^{\mathrm{b}}$ & $6.46^{\mathrm{a}}$ & $6.57^{\mathrm{a}}$ & 0.076 & 0.038 \\
\hline Maximum & $6.73^{\mathrm{b}}$ & $6.75^{\mathrm{b}}$ & $6.84^{\mathrm{b}}$ & $7.14^{\mathrm{a}}$ & 0.085 & 0.026 \\
\hline \multicolumn{7}{|l|}{ VFA } \\
\hline Total (mmol/L) & $66.7^{\mathrm{a}}$ & $73.2^{\mathrm{a}}$ & $57.0^{\mathrm{b}}$ & $36.8^{\mathrm{c}}$ & 2.25 & $<0.001$ \\
\hline \multicolumn{7}{|l|}{ Individual VFA (mol/100 mol) } \\
\hline Acetate $(\mathrm{A})$ & 64.48 & 62.95 & 65.35 & 64.71 & 1.363 & 0.627 \\
\hline Propionate (P) & 24.60 & 27.61 & 25.14 & 25.07 & 1.179 & 0.247 \\
\hline Butyrate (B) & $9.27^{\mathrm{ab}}$ & $8.84^{\mathrm{a}}$ & $9.0^{\mathrm{a}}$ & $10.22^{\mathrm{b}}$ & 0.367 & 0.049 \\
\hline Isobutyrate & $0.61^{\mathrm{a}}$ & $0.00^{\mathrm{b}}$ & $0.14^{\mathrm{b}}$ & $0.00^{\mathrm{b}}$ & 0.046 & $<0.001$ \\
\hline Valerate (V) & 0.92 & 0.60 & 0.37 & 0.00 & 0.302 & 0.249 \\
\hline Isovalerate & 0.12 & 0.00 & 0.00 & 0.00 & 0.062 & 0.436 \\
\hline $\mathrm{A}: \mathrm{P}$ & 2.62 & 2.38 & 2.60 & 2.58 & 0.135 & 0.202 \\
\hline $\mathrm{A}+\mathrm{B}: \mathrm{P}$ & 3.00 & 2.60 & 2.96 & 2.99 & 0.151 & 0.170 \\
\hline $\mathrm{A}+\mathrm{B}: \mathrm{P}+\mathrm{V}$ & 2.89 & 2.54 & 2.91 & 2.99 & 0.158 & 0.218 \\
\hline Protozoa $\left(\right.$ cells $\left.\times 10^{5} / \mathrm{mL}\right)$ & $2.13^{\mathrm{b}}$ & $2.23^{\mathrm{b}}$ & $2.14^{\mathrm{b}}$ & $2.88^{\mathrm{a}}$ & 0.081 & 0.002 \\
\hline \multicolumn{7}{|l|}{ Total $\mathrm{CH}_{4}$ production $(\mathrm{mg})$} \\
\hline $\mathrm{CH}_{4} / \mathrm{d}$ & $276.7^{\mathrm{a}}$ & $244.1^{\mathrm{ab}}$ & $207.1^{\mathrm{b}}$ & $28.4^{\mathrm{c}}$ & 43.38 & $<0.001$ \\
\hline $\mathrm{CH}_{4} / \mathrm{g}$ of $\mathrm{OM}$ & $3.6^{\mathrm{a}}$ & $3.2^{\mathrm{ab}}$ & $2.7^{\mathrm{b}}$ & $0.4^{\mathrm{c}}$ & 0.57 & $<0.001$ \\
\hline $\mathrm{CH}_{4} / \mathrm{g}$ of NDF & $6.5^{\mathrm{a}}$ & $6.7^{\mathrm{a}}$ & $5.8^{\mathrm{a}}$ & $0.8^{\mathrm{b}}$ & 1.11 & $<0.001$ \\
\hline $\mathrm{CH}_{4} / \mathrm{g}$ of digestible $\mathrm{OM}$ & $5.4^{\mathrm{a}}$ & $4.8^{\mathrm{ab}}$ & $4.2^{\mathrm{b}}$ & $0.6^{\mathrm{c}}$ & 0.84 & $<0.001$ \\
\hline $\mathrm{CH}_{4} / \mathrm{g}$ of digestible NDF & $6.4^{\mathrm{a}}$ & $5.5^{\mathrm{ab}}$ & $4.9^{\mathrm{b}}$ & $0.9^{\mathrm{c}}$ & 1.04 & $<0.001$ \\
\hline
\end{tabular}

${ }^{\mathrm{a}-\mathrm{c}}$ Means within a row with different superscripts differ $(P<0.05)$.

${ }^{1} \mathrm{ALF}=50 \%$ orchardgrass $+50 \%$ alfalfa; $\mathrm{BFT}=50 \%$ orchardgrass $+50 \%$ birdsfoot trefoil; $\mathrm{CV}=50 \%$ orchardgrass $+50 \%$ crown vetch; SL $=50 \%$ orchardgrass $+50 \%$ sericea lespedeza. 
continuous-culture fermentor studies (Soder et al., 2012, 2013) where fermentor $\mathrm{pH}$ was decreased by increasing nutrient digestibilities. Kolver and de Veth (2002) predicted that mean $\mathrm{pH}$ to optimize digestion of pasture was 6.35 , lower than that found in the current study; however, they also mentioned that nutrient digestion and synthesis of microbial protein were largely insensitive to $\mathrm{pH}$ across a broad range of $\mathrm{pH}$ values (5.8-6.8).

Total VFA were lower $(P<0.001)$ in SL and CV diets compared with ALF and BFT diets (Table 3). In the current study, a reduction in VFA production in those diets can be linked to decreased nutrient digestibilities and changes on the composition of ruminal microbiota (Vasta et al., 2019). There were no differences $(P>$ $0.05)$ among diets in molar proportions of acetate, propionate, valerate, isovalerate, or ratios of $\mathrm{A}: \mathrm{P}, \mathrm{A}+\mathrm{B}: \mathrm{P}$, and $\mathrm{A}+\mathrm{B}: \mathrm{P}+\mathrm{V}$ (when $\mathrm{A}=$ acetate, $\mathrm{P}=$ propionate, $\mathrm{B}$ = butyrate, and $\mathrm{V}=$ valerate). Molar proportions of butyrate were greater $(P<0.05)$ in the SL diet than in the BFT and CV diets. Contrarily, molar proportions of isobutyrate were higher $(P<0.001)$ in the ALF than in the other 3 diets. The relatively low isobutyrate and isovalerate values in this study may have been due to $\mathrm{CT}$ concentration of the diet. In a meta-analysis of the relationship between methane formation and dietary CT level, Jayanegara et al. (2012) showed an inverse relationship between branched-chain VFA (isobutyrate and isovalerate) and an increase in CT concentrations. Alternatively, Hristov et al. (2012) found that variability in VFA data was greater for continuous-culture fermentor systems compared with in vivo data.

Protozoal counts were greatest $(P<0.05)$ in the SL diet compared with the other 3 diets. Chiquette et al. (1989) observed that protozoal counts tended to increase when feeding ewes a CT-rich diet (3\% CT) compared with a low-CT diet (1\% CT), but was only a significant increase $3 \mathrm{~h}$ after feeding. Animut et al. (2008a) found a linear increase in protozoal counts as the percentage of CT-containing Kobe lespedeza (Lespedeza striata) was added to a sorghum-sudangrass (Sorghum bicolor) diet.

\section{Methane Production}

Total $\mathrm{CH}_{4}$ production $\left(\mathrm{mg}\right.$ of $\left.\mathrm{CH}_{4} / \mathrm{d}\right)$ was lower $(P<$ 0.001 ) in the SL diet than in the other 3 diets (Table 3 ). This decrease was mainly attributed to a reduction in apparent fiber digestion in the SL diet, but also to lowering apparent and true OM digestibilities. Furthermore, $\mathrm{CH}_{4}$ per gram of $\mathrm{OM}$, per gram of $\mathrm{NDF}$, per gram of digestible $\mathrm{OM}$, and per gram of digestible NDF fed were the lowest $(P<0.001)$ for the SL diet. No differences $(P>0.31)$ were observed among the other 3 diets for $\mathrm{CH}_{4}$ per gram of NDF fed. However, ALF had greater $\mathrm{CH}_{4}$ per gram of $\mathrm{OM}$ fed, digestible $\mathrm{OM}$ fed, and digestible NDF fed than CV or SL $(P=0.03,0.04$, and 0.04 , respectively). The high CT concentration in SL diet may decrease $\mathrm{CH}_{4}$ production by reducing fiber digestion (indirect effect), whereas hydrolysable tannins (such as those in sweet chestnut) act by inhibiting the growth or activity of methanogens or hydrogenproducing microbes (direct effect) (Goel and Makkar, 2012). Animut et al. (2008a) suggested that alterations in protozoal activity among diets differing in CT concentrations resulted in a change in supply of substrates to methanogens may be partly responsible for changes in $\mathrm{CH}_{4}$ emissions. Decreases in both $\mathrm{CH}_{4}$ production and in apparent total-tract $\mathrm{DM}$ and $\mathrm{OM}$ digestibilities found in goats fed lespedeza (Animut et al., 2008a,b) also support the idea that observed $\mathrm{CH}_{4}$ mitigation in the SL diet may be due to decreased nutrient digestibilities. Toxicity of phenols and other tannin fractions in the SL diet to rumen microbes and methanogens may also have contributed to the observed effect. Animut et al. (2008b) reported that inhibition of methanogens by CT might be a primary result of suppressed fiber degradation that limits $\mathrm{H}_{2}$ derived from synthesis of acetate. They suggest that depressed fiber degradation could be due to a reduced number of cellulolytic bacteria, formation of tannin-cellulose complexes, or impaired bacterial adhesion to substrate and fibrolytic activity of rumen microbes.

Decreased $\mathrm{CH}_{4}$ emissions and pasture DMI were previously reported by Puchala et al. (2005) after feeding Angora goats sericea lespedeza (177 g of CT $/ \mathrm{kg}$ of DM) versus crabgrass [Digitaria ischaemum (Schreb.) Schreb. ex Muhl.]/tall fescue [Schedonorus arundinaceus (Schreb.) Dumort., nom. cons.; without CT], respectively. Animut et al. (2008a) also observed that feeding different levels of Kobe lespedeza dosed at 1:2, 2:1, and 3:0 in a mixture with sorghum-sudangrass reduced $\mathrm{CH}_{4}$ production linearly in goats, which was attributed to the presence of CT in that legume. Furthermore, Animut et al. (2008b) reported a reduction in $\mathrm{CH}_{4}$ emissions $(51 \%)$ produced by goats fed sericea lespedeza (140 g of CT $/ \mathrm{kg}$ of DM) as sole feed compared with diets with polyethylene glycol (which deactivates CT).

\section{Nitrogen Metabolism}

Nitrogen intake was greater $(P<0.001)$ in ALF, BFT, and CV diets than in the SL diet (Table 4). Fermentor $\mathrm{NH}_{3}-\mathrm{N}$ concentrations were greater $(P<0.001)$ in ALF than in BFT and SL diets, with the CV diet showing an intermediate level. True CP degradability was greater $(P=0.02)$ in ALF and CV diets than in 
Table 4. Nitrogen metabolism of alfalfa, birdsfoot trefoil, crown vetch, and sericea lespedeza fed with orchardgrass during continuous-culture fermentation

\begin{tabular}{|c|c|c|c|c|c|c|}
\hline \multirow[b]{2}{*}{ Item } & \multicolumn{4}{|c|}{$\operatorname{Diet}^{1}$} & \multirow[b]{2}{*}{ SEM } & \multirow[b]{2}{*}{$P$-value } \\
\hline & ALF & $\mathrm{BFT}$ & $\mathrm{CV}$ & SL & & \\
\hline $\mathrm{N}_{\text {intake }}^{2}(\mathrm{~g} / \mathrm{d})$ & $4.04^{\mathrm{a}}$ & $3.44^{\mathrm{b}}$ & $3.35^{\mathrm{c}}$ & $3.07^{\mathrm{d}}$ & 0.006 & $<0.001$ \\
\hline $\mathrm{NH}_{3}-\mathrm{N}(\mathrm{mg} / \mathrm{dL})$ & $22.5^{\mathrm{a}}$ & $9.3^{\mathrm{c}}$ & $17.6^{\mathrm{b}}$ & $11.2^{\mathrm{c}}$ & 0.74 & $<0.001$ \\
\hline True CP degradability (\%) & $90.8^{\mathrm{a}}$ & $75.7^{\mathrm{b}}$ & $93.6^{\mathrm{a}}$ & $72.9^{\mathrm{b}}$ & 4.48 & 0.020 \\
\hline \multicolumn{7}{|l|}{$\mathrm{N}$ flows $(\mathrm{g} / \mathrm{d})$} \\
\hline Total N & $2.57^{\mathrm{a}}$ & $2.72^{\mathrm{a}}$ & $2.34^{\mathrm{b}}$ & $2.24^{\mathrm{b}}$ & 0.076 & 0.001 \\
\hline $\mathrm{NH}_{3}-\mathrm{N}$ & $0.96^{\mathrm{a}}$ & $0.40^{\mathrm{c}}$ & $0.75^{\mathrm{b}}$ & $0.47^{\mathrm{c}}$ & 0.032 & $<0.001$ \\
\hline Non- $\mathrm{NH}_{3}-\mathrm{N}$ & $1.61^{\mathrm{b}}$ & $2.33^{\mathrm{a}}$ & $1.59^{\mathrm{b}}$ & $1.76^{\mathrm{b}}$ & 0.072 & $<0.001$ \\
\hline Bacterial N & $1.31^{\mathrm{bc}}$ & $1.68^{\mathrm{a}}$ & $1.43^{\mathrm{b}}$ & $1.14^{\mathrm{c}}$ & 0.071 & 0.003 \\
\hline Dietary N & $0.30^{\mathrm{ab}}$ & $0.65^{\mathrm{a}}$ & $0.16^{\mathrm{b}}$ & $0.62^{\mathrm{a}}$ & 0.110 & 0.031 \\
\hline \multicolumn{7}{|l|}{ Bacterial efficiency } \\
\hline OM truly digested ( $\mathrm{g}$ of $\mathrm{N} / \mathrm{kg}$ ) & $22.5^{\mathrm{bc}}$ & $27.0^{\mathrm{a}}$ & $24.5^{\mathrm{ab}}$ & $21.0^{\mathrm{c}}$ & 1.09 & 0.013 \\
\hline
\end{tabular}

BFT and SL diets. The decreased degradability of CP in the SL diet may be attributed to the formation of tannin-protein complexes that prevent degradation by rumen microbes, which is beneficial for post-ruminal utilization (Mueller-Harvey, 2006). It has been proposed that higher concentrations of $\mathrm{CT}$ in diets, such as those found in the SL diet, which remain free after binding with proteins, may depress fiber digestion by complexing with lignocellulose, thus preventing microbial digestion or by directly inhibiting cellulolytic microorganisms and activities of fibrolytic enzymes, or both (Patra and Saxena, 2010).

Effluent total $\mathrm{N}$ was greater $(P=0.001)$ in ALF and BFT diets than in CV and SL diets (Table 4). Effluent $\mathrm{NH}_{3}-\mathrm{N}$ was highest $(P<0.001)$ in ALF diet and lowest in BFT and SL diets. Effluent non- $\mathrm{NH}_{3}-\mathrm{N}$ was greater $(P<0.001)$ in the BFT diet than in the other 3 diets. Bacterial $\mathrm{N}$ flow was highest $(P=0.003)$ in the BFT diet. Dietary N flow was greater $(P=0.031)$ in BFT and SL diets than in the CV diet; however, ALF showed an intermediate level among them. Bacterial efficiency ( $\mathrm{g} \mathrm{N} / \mathrm{kg}$ of OM truly digestible) was greater $(P$ $=0.013)$ in the BFT diet than in the SL diet; however, ALF and CV diets showed intermediate levels between them.

While the amount of DM fed was kept constant in all fermentors, $\mathrm{N}$ intake differed across diets due to differences in CP concentration of diets. It is expected that the increase in dietary $\mathrm{CP}$ fed (related to diets tested with SL, CV, BFT, and ALF) would result in increased non- $\mathrm{NH}_{3}-\mathrm{N}$ flow, as well as flows of $\mathrm{NH}_{3}-\mathrm{N}$ and bacterial $\mathrm{N}$ due to greater $\mathrm{N}$ input into the system (Brandao and Faciola, 2019). Fermentor $\mathrm{NH}_{3}-\mathrm{N}$ concentrations are in line with those reported in previous studies conducted by Williams et al. (2010), where a reduction in $\mathrm{NH}_{3} \mathrm{~N}$ concentrations $(27.8 \%)$ and flow $(26 \%)$ occurred with birdsfoot trefoil compared with alfalfa in continuous cultures fed with 55:45 forage to concentrate ratio. According to Brandao and Faciola (2019), fermentors fed with high CP diets (such as ALF in the current study) showed greater $\mathrm{NH}_{3}-\mathrm{N}$ accumulation than those fed low $\mathrm{CP}$ diets (such as BFT, CV, and SL in the current study). However, the reduction in $\mathrm{NH}_{3}-\mathrm{N}$ concentration and flow in the SL diet is notable because the SL diet contained the highest content of $\mathrm{CT}$, which may have resulted in increased $\mathrm{N}$ binding, as shown by its lower RDP concentration. Devant et al. (2000) showed that degradability of $\mathrm{CP}$ in the rumen affects $\mathrm{N}$ digestibility and retention. Therefore, it is important to maintain a minimum concentration of ruminal $\mathrm{NH}_{3}-\mathrm{N}$, not only for adequate microbial fermentation, but also for adequate fiber digestion. Due to differences in true CP degradability among diets, it can be hypothesized that the rate of $\mathrm{NH}_{3}-\mathrm{N}$ release from $\mathrm{ALF}$ diet (without $\mathrm{CT}$ ) was greater than that of the 3 diets containing CT. Previous studies (Soder et al., 2012, 2013) also showed lower $\mathrm{NH}_{3}-\mathrm{N}$ concentrations, $\mathrm{N}$ flows (total $\mathrm{N}, \mathrm{NH}_{3}-\mathrm{N}$, non$\mathrm{NH}_{3}-\mathrm{N}$, and bacterial $\mathrm{N}$ ), and bacterial efficiency by using a $100 \%$ orchardgrass diet compared with a 50:50 orchardgrass:alfalfa mixture (similar to that tested in the current study). At high CT concentrations, lower bacterial efficiency and total VFA concentration were observed in the SL diet, suggesting that overall ruminal fermentation might be compromised due to low nutrient digestibilities.

\section{CONCLUSIONS}

Condensed tannin concentrations significantly influenced in vitro ruminal fermentation and enteric $\mathrm{CH}_{4}$ 
production in diets containing 50:50 grass:legume. When compared with cool-season perennial legume diets (ALF, BFT, and CV), the warm-season legume SL diet, which also contained the greatest CT concentrations, had decreased apparent NDF and ADF digestibilities, total VFA concentration, $\mathrm{N}$ intake, and total $\mathrm{CH}_{4}$ production. In addition, the lowest apparent and true DM and $\mathrm{OM}$ digestibilities and bacterial $\mathrm{N}$ efficiency per $\mathrm{kg}$ of OM truly digested were found in the SL diet. However, tradeoffs in ruminal fermentation (reduced nutrient digestibilities, total VFA concentration, and bacterial $\mathrm{N}$ efficiency) must be considered when SL (a high-CT legume) is used to lower $\mathrm{CH}_{4}$ production. Legumes containing moderate concentrations of $\mathrm{CT}$ also decreased $\mathrm{CH}_{4}$ production compared with the ALF diet, but with less negative effects on ruminal fermentation. Further work should be conducted in vitro to find optimal diets (e.g., testing other legumes, rations, and concentrations of $\mathrm{CT}$ ) that reduce $\mathrm{CH}_{4}$ emissions without negatively affecting ruminal digestion.

\section{ACKNOWLEDGMENTS}

The authors thank C. Dell, M. Rubano, J. Everhart, R. Stout, and R. Tillmann (USDA-ARS); J. MacAdam (Utah State University); and J. Dillon (Pennsylvania State University) for laboratory expertise and time contributed to conducting this experiment. The project was partially funded by USDA-NIFA-OREI (Project number: 8070-21000-008-16, 2011-2016) and Xunta de Galicia - Plan I2C - Modality A (Project Number: POS-A/2014-021). USDA is an equal opportunity provider and employer. The authors have not stated any conflicts of interest.

\section{REFERENCES}

Aerts, R. J., T. N. Barry, and W. C. McNabb. 1999. Polyphenols and agriculture: Beneficial effects of proanthocyanidins in forages. Agric. Ecosyst. Environ. 75:1-12. https://doi.org/10.1016/S0167 -8809(99)00062-6.

Animut, G., R. Puchala, A. L. Goetsch, A. K. Patra, T. Sahlu, V. H. Varel, and J. Wells. 2008a. Methane emission by goats consuming diets with different levels of condensed tannins from lespedeza. Anim. Feed Sci. Technol. 144:212-227. https://doi.org/10.1016/j .anifeedsci.2007.10.014.

Animut, G., R. Puchala, A. L. Goetsch, A. K. Patra, T. Sahlu, V. H. Varel, and J. Wells. 2008b. Methane emission by goats consuming different sources of condensed tannins. Anim. Feed Sci. Technol. 144:228-241. https://doi.org/10.1016/j.anifeedsci.2007.10.015.

AOAC International. 2006. Official Methods of Analysis. 18th ed. AOAC International, Gaithersburg, MD.

Athanasiadou, S., I. Kyriazakis, F. Jackson, and R. L. Coop. 2001. Direct anthelmintic effects of condensed tannins towards different gastrointestinal nematodes of sheep: In vitro and in vivo studies. Vet. Parasitol. 99:205-219. https://doi.org/10.1016/S0304 $-4017(01) 00467-8$.

Barry, T. N., and D. A. Forss. 1983. The condensed tannin content of vegetative Lotus pedunculatus, its regulation by fertilizer ap- plication, and effect upon protein solubility. J. Sci. Food Agric. 34:1047-1056. https://doi.org/10.1002/jsfa.2740341004.

Bhatta, R., Y. Uyeno, K. Tajima, A. Takenaka, Y. Yabumoto, I. Nonaka, O. Enishi, and M. Kurihara. 2009. Difference in the nature of tannins on in vitro ruminal methane and volatile fatty acid production and on methanogenic archaea and protozoal populations. J. Dairy Sci. 92:5512-5522. https://doi.org/10.3168/jds.2008-1441.

Bodas, R., N. Prieto, R. García-González, S. Andrés, F. J. Giráldez, and S. López. 2012. Manipulation of rumen fermentation and methane production with plant secondary metabolites. Anim. Feed Sci. Technol. 176:78-93. https://doi.org/10.1016/j.anifeedsci.2012 .07 .010 .

Brandao, V. L. N., and A. P. Faciola. 2019. Unveiling the relationships between diet composition and fermentation parameters response in dual-flow continuous culture system: a meta-analytical approach. Transl. Anim. Sci. 3:1064-1075. https://doi.org/10.1093/tas/ txz019.

Broderick, G. A., J. H. Grabber, R. E. Muck, and U. C. Hymes-Fecht. 2017. Replacing alfalfa silage with tannin-containing birdsfoot trefoil silage in total mixed rations for lactating dairy cows. J. Dairy Sci. 100:3548-3562. https://doi.org/10.3168/jds.2016-12073.

Buxton, D. R., and D. D. Redfearn. 1997. Plant limitations to fiber digestion and utilization. J. Nutr. 127(5 Suppl):814S-818S. https: //doi.org/10.1093/jn/127.5.814S.

Chaney, A. L., and E. P. Marbach. 1962. Modified reagents for determination of urea and ammonia. Clin. Chem. 8:130-132. https:// doi.org/10.1093/clinchem/8.2.130.

Chiquette, J., K. J. Cheng, L. M. Rode, and L. P. Milligan. 1989. Effect of tannin content in two isosynthetic strains of birdsfoot trefoil (Lotus corniculatus L.) on feed digestibility and rumen fluid composition in sheep. Can. J. Anim. Sci. 69:1031-1039. https:// doi.org/10.4141/cjas89-117.

Coblentz, W. K., I. E. Abdelgadir, R. C. Cochran, J. O. Fritz, W. H. Fick, K. C. Olson, and J. E. Turner. 1999. Degradability of forage proteins by in situ and in vitro enzymatic methods. J. Dairy Sci. 82:343-354. https://doi.org/10.3168/jds.S0022-0302(99)75241-0.

Dehority, B. A. 2005. Ciliate protozoa. Pages $67-78$ in Methods in Gut Microbial Ecology for Ruminants. H. P. S. Makkar and C. S. McSweeney, ed. Springer, Dordrecht, the Netherlands.

Devant, M., A. Ferret, J. Gasa, S. Calsamiglia, and R. Casals. 2000. Effects of protein concentration and degradability on performance, ruminal fermentation, and nitrogen metabiolism in rapidly growing heifers fed high-concentrate diets from 100 to $230 \mathrm{~kg}$ body weight. J. Anim. Sci. 78:1667-1676. https://doi.org/10.2527/2000 $.7861667 \mathrm{x}$

Díaz Carrasco, J. M., C. Cabral, L. Martín Redondo, N. D. Pin Viso, D. Colombatto, M. D. Farber, and M. E. Fernández Miyakawa. 2017. Impact of chestnut and quebracho tannins on rumen microbiota of bovines. BioMed Res. Int. 2017:9610810. https://doi.org/ $10.1155 / 2017 / 9610810$.

Dillard, S. L., A. N. Hafla, A. I. Roca-Fernández, A. F. Brito, M. D. Rubano, and K. J. Soder. 2017. Effect of feeding warm-season annuals with orchardgrass on ruminal fermentation and methane output in continuous culture. J. Dairy Sci. 100:1179-1188. https:/ /doi.org/10.3168/jds.2016-11510.

Dillard, S. L., A. I. Roca-Fernández, M. D. Rubano, and K. J. Soder. 2019. Evaluation of a novel continuous culture fermentor system for determination of ruminal fermentation and methane production. J. Anim. Physiol. Anim. Nutr. (Berl.) 103:1313-1324. https: //doi.org/10.1111/jpn.13155.

Erwin, E. S., G. J. Marco, and E. M. Emery. 1961. Volatile fatty acid analysis of blood and rumen fluid by gas chromatography. J. Dairy Sci. 44:1768-1771. https://doi.org/10.3168/jds.S0022 -0302(61)89956-6.

Foskolos, A., A. Siurana, M. Rodriquez-Prado, A. Ferret, D. Bravo, and S. Calsamiglia. 2015. The effects of a garlic oil chemical compound, propyl-propane thiosulfonate, on ruminal fermentation and fatty acid outflow in a dual-flow continuous culture system. J. Dairy Sci. 98:5482-5491. https://doi.org/10.3168/jds.2014-8674. 
Goel, G., and H. P. S. Makkar. 2012. Methane mitigation from ruminants using tannins and saponins. Trop. Anim. Health Prod. 44:729-739. https://doi.org/10.1007/s11250-011-9966-2.

Grabber, J. H., W. E. Zeller, and I. Mueller-Harvey. 2013. Acetone enhances the direct analysis of procyanidin- and prodelphinidinbased condensed tannins in lotus species by the butanol-HCl-iron assay. J. Agric. Food Chem. 61:2669-2678. https://doi.org/10 $.1021 /$ jf304158m.

Griswold, K. E., W. H. Hoover, T. K. Miller, and W. V. Thayne. 1996. Effect of form of nitrogen on rumen microbes in continuous culture. J. Anim. Sci. 74:483-491.https://doi.org/10.2527/1996.742483x.

Hristov, A. N., C. Lee, R. Hristova, P. Huhtanen, and J. L. Firkins. 2012. A meta-analysis of variability in continuous-culture ruminal fermentation and digestibility data. J. Dairy Sci. 95:5299-5307. https://doi.org/10.3168/jds.2012-5533.

Jayanegara, A., F. Leiber, and M. Kreuzer. 2012. Meta-analysis of the relationship between dietary tannin level and methane formation in ruminants from in vivo and vitro experiments. J. Anim. Physiol. Anim. Nutr. (Berl.) 96:365-375. https://doi.org/10.1111/ j.1439-0396.2011.01172.x.

Jones, G. A., T. A. McAllister, A. D. Muir, and K. J. Cheng. 1994. Effects of sainfoin (Onobrichys viciifolia Scop.) condensed tannins on growth and proteolysis by four strains of ruminal bacteria. Appl. Environ. Microbiol. 60:1374-1378. https://doi.org/10.1128/AEM 60.4.1374-1378.1994.

Jonker, A., and P. Yu. 2017. The occurrence, biosynthesis, and molecular structure of proanthocyanidins and their effects on legume forage protein precipitation, digestion and absorption in the ruminant digestive tract. Int. J. Mol. Sci. 18:1105. https://doi.org/10 $.3390 /$ ijms18051105.

Kamra, D. N., A. K. Patra, P. N. Chatterjee, R. Kumar, N. Agarwal, and L. C. Chaudhary. 2008. Effect of plant extract on methanogenesis and microbial profile of the rumen of buffalo: A brief overview. Aust. J. Exp. Agric. 48:175-178. https://doi.org/10.1071/ EA07268.

Kolver, E. S., and M. J. de Veth. 2002. Prediction of ruminal pH from pasture-based diets. J. Dairy Sci. 85:1255-1266. https://doi.org/10 .3168/jds.S0022-0302(02)74190-8.

Lascano, G. J., M. Alende, L. E. Koch, and T. C. Jenkins. 2016. Changes in fermentation and biohydrogenation intermediates in continuous cultures fed low and high levels of fat with increasing rates of starch degradability. J. Dairy Sci. 99:6334-6341. https:// doi.org/10.3168/jds.2016-11032.

Li, Y., D. Iwaasa, Y. Wang, L. Jin, G. Han, and M. Zhao. 2014. Condensed tannins concentration of selected prairie legume forages as affected by phenological stages during two consecutive growth seasons in western Canada. Can. J. Plant Sci. 94:817-826. https:/ /doi.org/10.4141/cjps2013-234.

Licitra, G., T. M. Hernandez, and P. J. Van Soest. 1996. Standardization of procedures for nitrogen fractionation of ruminant feeds. Anim. Feed Sci. Technol. 57:347-358. https://doi.org/10.1016/ 0377-8401(95)00837-3.

Makkar, H. P., and K. Becker. 1999. Purine quantification in digesta from ruminants by spectrophotometric and HPLC methods. Br. J. Nutr. 81:107-112. https://doi.org/10.1017/S0007114599000227.

McAllister, T. A., H. D. Bae, L. J. Yanke, K.-J. Cheng, and A. Muir . 1994. Effect of condensed tannins from birdsfoot trefoil on the endoglucanase activity and the digestion of cellulose filter paper by ruminal fungi. Can. J. Microbiol. 40:298-305. https://doi.org/ $10.1139 / \mathrm{m} 94-048$.

Mertens, D. R. 2002. Gravimetric determination of amylase-treated neutral detergent fiber in feeds with refluxing in beakers or crucibles: Collaborative study. J. AOAC Int. 85:1217-1240.

Min, B. R., W. E. Pinchak, R. C. Anderson, J. D. Fulford, and R. Puchala. 2006. Effects of condensed tannins supplementation level on weight gain and in vitro and in vivo bloat precursors in steers grazing winter wheat. J. Anim. Sci. 84:2546-2554. https://doi.org/ $10.2527 /$ jas. 2005-590.

Moore, D. A., T. H. Terrill, B. Kouakou, S. A. Shaik, J. A. Mosjidis, J. E. Miller, M. Vanguru, G. Kannan, and J. M. Burke. 2008. The effects of feeding sericea lespedeza hay on growth rate of goats naturally infected with gastrointestinal nematodes. J. Anim. Sci. 86:2328-2337. https://doi.org/10.2527/jas.2007-0411.

Mueller-Harvey, I. 2006. Unravelling the conundrum of tannins in animal nutrition and health. J. Sci. Food Agric. 86:2010-2037. https: //doi.org/10.1002/jsfa.2577.

Müir, J. P., T. H. Terrill, J. A. Mosjidis, J. M. Luginbuhl, J. E. Miller, J. M. Burke, and S. W. Coleman. 2018. Harvest regimen changes sericea lespedeza condensed tannin, fiber and protein concentrations. Grassl. Sci. 64:137-144. https://doi.org/10.1111/grs.12186.

NRC. 2001. Nutrient Requirements of Dairy Cattle. 7th rev. ed. National Academy Press, Washington, DC.

Patra, A. K., and J. Saxena. 2009. Dietary phytochemicals as rumen modifiers: A review of the effects on microbial populations. Antonie van Leeuwenhoek 96:363-375. https://doi.org/10.1007/ s10482-009-9364-1.

Patra, A. K., and J. Saxena. 2010. A new perspective on the use of plant secondary metabolites to inhibit methanogenesis in the rumen. Phytochemistry 71:1198-1222. https://doi.org/10.1016/j .phytochem.2010.05.010

Patra, A. K., and J. Saxena. 2011. Exploitation of dietary tannins to improve rumen metabolism and ruminant nutrition. J. Sci. Food Agric. 91:24-37. https://doi.org/10.1002/jsfa.4152.

Puchala, R., G. Animut, A. K. Patra, G. D. Detweiler, J. E. Wells, V. H. Varel, T. Sahlu, and A. L. Goetsch. 2012. Effects of different fresh-cut forages and their hays on feed intake, digestibility, heat production, and ruminal methane emission by Boer $\mathrm{x}$ Spanish goats. J. Anim. Sci. 90:2754-2762. https://doi.org/10.2527/jas .2011-4879.

Puchala, R., B. R. Min, A. L. Goetsch, and T. Sahlu. 2005. The effect of a condensed tannin-containing forage on methane emission by goats. J. Anim. Sci. 83:182-186. https://doi.org/10.2527/2005 $.831182 x$.

Rochfort, S., A. J. Parker, and F. R. Dunshea. 2008. Plant bioactives for ruminant health and productivity. Phytochemistry 69:299-322. https://doi.org/10.1016/j.phytochem.2007.08.017.

Schreurs, N. M., M. H. Tavendale, G. A. Lane, T. N. Barry, N. LópezVillalobos, and W. C. McNabb. 2007. Effect of different condensed tannin-containing forages, forage maturity and nitrogen fertiliser application on the formation of indole and skatole inin vitro rumen fermentations. J. Sci. Food Agric. 87:1076-1087. https://doi.org/ 10.1002/jsfa.2814.

Soder, K. J., A. F. Brito, A. N. Hafla, and M. D. Rubano. 2016. Effect of starchy of fibrous carbohydrate supplementation of orchardgrass on ruminal fermentation and methane output in continuous culture. J. Dairy Sci. 99:4464-4475. https://doi.org/10.3168/jds.2015 $-10471$.

Soder, K. J., A. F. Brito, and M. D. Rubano. 2013. Effect of supplementing orchardgrass herbage with a total mixed ration or flaxseed on fermentation profile and bacterial protein synthesis in continuous culture. J. Dairy Sci. 96:3228-3237. https://doi.org/10 $.3168 /$ jds.2012-6307.

Soder, K. J., A. F. Brito, M. D. Rubano, and C. J. Dell. 2012. Effect of incremental flaxseed supplementation of an herbage diet on methane output and ruminal fermentation in continuous culture. J. Dairy Sci. 95:3961-3969. https://doi.org/10.3168/jds.2011-4981.

Terrill, T. H., A. M. Rowan, G. B. Douglas, and T. N. Barry. 1992. Determination of extractable and bound condensed tannin concentrations in forage plants, protein concentrate meals and cereal grains. J. Sci. Food Agric. 58:321-329. https://doi.org/10.1002/ jsfa. 2740580306.

Theodoridou, K., J. Aufrère, D. Andueza, J. Pourrat, A. Le Morvan, E. Stringano, I. Mueller-Harvey, and R. Baumont. 2010. Effects of condensed tannins in fresh sainfoin (Onobrychis viciifolia) on in vivo and in situ digestion in sheep. Anim. Feed Sci. Technol. 160:23-38. https://doi.org/10.1016/j.anifeedsci.2010.06.007.

Van Soest, P. J. 1994. Page 363 in Nutritional Ecology of the Ruminant. 2nd ed. Cornell University Press, Ithaca, NY

Van Soest, P. J., J. B. Robertson, and B. A. Lewis. 1991. Methods for dietary fiber, neutral detergent fiber and nonstarch polysaccharides in relation to animal nutrition. J. Dairy Sci. 74:3583-3597. https://doi.org/10.3168/jds.S0022-0302(91)78551-2. 
Vasta, V., M. Daghio, A. Cappucci, A. Buccioni, A. Serra, C. Viti, and M. Mele. 2019. Invited review: Plant polyphenols and rumen microbiota responsible for fatty acid biohydrogenation, fiber digestion, and methane emission: Experimental evidence and methodological approaches. J. Dairy Sci. 102:3781-3804. https://doi.org/ $10.3168 /$ jds.2018-14985.

Waghorn, G. 2008. Beneficial and detrimental effects of dietary condensed tannins for sustainable sheep and goat production-Progress and challenges. Anim. Feed Sci. Technol. 147:116-139. https://doi .org/10.1016/j.anifeedsci.2007.09.013.

Williams, C. M., J. S. Eun, C. M. Dschaak, J. W. MacAdam, B. R. Min, and A. J. Young. 2010. Case study: in vitro ruminal fermentation characteristics of birdsfoot trefoil (Lotus corniculatus L.) hay in continuous cultures. Prof. Anim. Sci. 26:570-576. https:// doi.org/10.15232/S1080-7446(15)30646-X.

Williams, C. M., J. S. Eun, J. W. MacAdam, A. J. Young, V. Fellner, and B. R. Min. 2011. Effect of forage legumes containing condensed tannins on methane and ammonia production in continuous cultures of mixed ruminal microorganisms. Anim. Feed Sci.
Technol. 166-167:364-372. https://doi.org/10.1016/j.anifeedsci 2011.04.025.

Yáñez-Ruiz, D. R., A. Bannink, J. Dijkstra, E. Kebreab, D. P. Morgavi, P. O'Kiely, C. K. Reynolds, A. Schwarm, K. J. Shingfield, Z. $\mathrm{Yu}$, and A. N. Hristov. 2016. Design, implementation and interpretation of in vitro batch culture experiments to assess enteric methane mitigation in ruminants-a review. Anim. Feed Sci. Technol. 216:1-18. https://doi.org/10.1016/j.anifeedsci.2016.03.016.

Yoshida, T., T. Hatano, and H. Ito. 2005. High molecular weight plant polyphenols (tannins): Prospective functions. Recent Adv. Phytochem. 39:163-190. https://doi.org/10.1016/S0079-9920(05)80008 -5 .

\section{ORCIDS}

Ana I. Roca-Fernández @ https://orcid.org/0000-0002-2262-6157

S. Leanne Dillard @ https://orcid.org/0000-0002-4704-281X

Kathy J. Soder @ https://orcid.org/0000-0001-6331-243X 